\title{
Gastropods of the Lower Jurassic Hierlatz Limestone Formation, part 2. Some new archaic type slit-bearing components from the fauna of the Hierlatz Alpe (Hallstatt, Austria) and the Bakony Mts (Hungary)
}

\author{
János SzABó \\ Department of Palaeontology and Geology, Hungarian Natural History Museum, \\ H-1083 Budapest, Ludovika tér 2, Hungary.E-mail: szabo.janos@nhmus.hu
}

\begin{abstract}
This paper presents the taxonomic classification of gastropod specimens mainly from yet unpublished parts of collections of the Early Jurassic Hierlatz Limestone fauna. The discussed species most probably belong to such higher rank taxa that have been formerly thought to become extinct during the Late Triassic crisis and represent groups typical of Palaeozoic to Triassic times. The new taxa are: Wortheniopsis rakusi n. sp., Wortheniopsis bakonyensis n. sp., Foveolaria n. gen., Foveolaria bicarinata n. sp., Foveolaria conoidea n. sp., Foveolaria globosa n. sp., Foveolaria suemegensis n. sp., Foveolaria kocsisi n. sp. and Foveolaria sp. (?Pithodeidae), and Cyclostomaria praemonarii n. sp. (Gosseletinidae). With 40 figures.
\end{abstract}

Key words - Cyclostomaria, Foveolaria n. gen., Gastropoda, Jurassic, Wortheniopsis

\section{INTRODUCTION}

The Hierlatz Limestone is one of the Lower Jurassic lithological formations, which yields a diverse gastropod fauna providing excellent opportunity to investigate the recovery of the Tethyan benthic faunas after the Late Triassic mass extinction. Following a revision of the type material (SzABó 2009) presented in former publications (Hörnes in HAUER 1853; STOLICzKa 1861), the next studies focus on the gastropod material from different localities of the Hierlatz Limestone Formation that has long been stored in the museum collections but has never been described. This material consists of high number of specimens, and assessing the number of taxa they represent is essential in the recognition of the real diversity of the gastropod faunas in the Hierlatz Limestone Formation. Usually, these specimens are poorly preserved, hardly identifiable and therefore they remained as an admixture to the collections of better known taxa or were simply ignored. Many of them preserved enough details to find their systematic place on various taxonomic levels; some even support establishment of new taxa. 
Several specimens of the old Hierlatz Limestone collection in the Geologische Bundesanstalt, Vienna, formerly labelled as "Pleurotomaria foveolata J. A. Eudes-Deslongchamps, 1849" give an occasion to solve some taxonomic problems that are connected to this species name. First Sieberer (1907) then KuHN (1936), SzABó (1980), Fischer \& Weber (1997) and Szabó (2009) used the genus name Sisenna Koken, 1896 to express the differences of Pleurotomaria foveolata and the related species from Pleurotomaria Defrance, 1826. However, as GRÜNDEL \& NÜTZEL (2015) have remarked, the strong, sparse and predominant spiral ornament of keels, the peculiar selenizone in the type species of Sisenna distinguish it from the "foveolata" group. Therefore these species are provided with a new generic name herein. Since the species of the new genus are thought to be morphologically related to Wortheniopsis J. Böhm, 1895 (SzA Bó 2009), a review on the syntypes of its type species has also been completed to confirm the former assumption.

\section{MATERIAL, LOCALITY}

The main part of the studied material belongs to the collection of the Museum of the Geologische Bundesanstalt Vienna, Austria. Most likely, it has already been assembled when the first extensive descriptions of the Hierlatz Limestone gastropods were published (Hörnes in HAUER 1853; STOLICZKA 1861). Majority of the specimens, discussed below, are found in the "background material" that has been kept separately from the collection of "originals", figured in STOLICZKA (1861). All have been collected in the type locality area of the Hierlatz Limestone (Hierlatz Alpe, Hallstatt, Austria). The outcrops are in the summit region above the Hierlatzwand, steeply rising at the S-SW edge of town Hallstatt. Most of them have been found on the S-SE slope of the mount during two revisits in the late 1990s. Several larger holes and heaps of debris indicate the spots of the former intensive collecting activity. These points are scattered on the slope and are connected to the widest dykes. Definite correlation has not been recognised between the museum collections of the gastropod fauna and the old excavations. However, it seems sure that the museum material was collected from different outcrops and/or beds since a code of numbers and colour spots are added to most of the specimens that do not correlate to taxonomy. The key to this information is not associated with the collection.

The outcrops belong to a Lower Jurassic sedimentary dyke network, infilling mostly subvertical fissures of Upper Triassic Dachstein Limestone but some elements are parallel to the bedding plane of the host strata. Their thickness extends from the microscopic dimensions to a few metres. The fissure-fillings show 
traces of episodic sedimentation and sometimes also clear facies dissimilarities that may indicate different source of the sediments and may mean also different time of deposition. Following the revisits, RAKús (1999) demonstrated that certain fissures had been repeatedly filled, which was confirmed by ammonites from the new collection. For additional information about the Hierlatz Limestone Formation, see Vörös (1991).

Abundant and diverse ammonite fauna is documented in several publications (Hauer 1853, 1854a, b, 1856; GeYer 1886; RAKús 1999). As GeYer (1886) summarized, the early authors concluded that the age of the Hierlatz Limestone in the type locality area is Lotharingian (Sinemurian) and the ammonites belong mainly to the Oxynotum Zone. Majority of the gastropod specimens are labelled in accordance with this opinion when the stratigraphical position is indicated. In his revision of the Hierlatz Alpe ammonites, RAKús (1999) provided wider stratigraphical interval for the deposition of the Hierlatz Limestone in this area, starting with the Semicostatum Zone (Lower Sinemurian) and terminating with the Jamesoni Zone (lowermost Pliensbachian). While the ammonites are today attributable to particular stratigraphical levels, the gastropods are not. They are now separated from ammonoid collections and potentially mixed up together with specimens from different stratigraphical levels.

Some additional specimens discussed herein from localities of the Bakony Mts (Hungary), were formerly provisionally identified in SzABó (1980, 2009).

Typically, the fossils and also the matrix are fully and coarsely re-crystallized in the Hierlatz Limestone, therefore their cleaning is risky and that is why the additional preparation of the monotypes has not been attempted.

The studied specimens are housed in the Museum of the Geologische Bundesanstalt, Vienna, Austria (GBA), the Naturhistorisches Museum, Vienna, Austria (NHMV) and in the Museum of the Geological and Geophysical Institute of Hungary, Budapest, Hungary (GGIH).

\section{SYSTEMATIC PALAEONTOLOGY}

In this paper the terminology of KNIGHT et al. (1960) is followed but with some modifications. The term "selenizone" is defined for the anal fasciole of dibranchiate gastropod shells but it is applied for two main, substantially different types of this anatomical/morphological component in the systematical chapters by KNIGHT et al. (1960). One type characterizes the gastropods that apply the deepest part of an outer lip sinus as anal outlet; in this case the growth lines remain clearly continuous. This kind of anal fasciole is called as sinuszone in this paper. In the other type, the growth lines and the transverse ornament are discon- 
tinuous; they terminate at the rims of the anal fasciole, just like the lunuliform/ seleniform growth lines and riblets/lunulae of the fasciole. The term selenizone is used exclusively for the latter morphology in this paper. This type is regarded as trace of an exhalant slit on the outer lip or a trema near the peristome. The morphological differences between the sinuszone and selenizone are thought to bear distinctive value at least on the genus level.

Kittl (1899, p. 14, Fig. 2.) called attention to a peculiar ornament type in his studies on Turbo quirini Stoppani, 1858, unified with Turbo funiculatus Stoppani, 1858 and identified as Wortheniopsis. Here, it is called "quirinii type" ridge (Figs 1-3) that means a spirally built asymmetrical, sharp elevation, multiplied on the base, and on the outer face of the whorls in certain shells. These ridges have nearly triangular axial cross-section with steep and narrow slope on the adapical and gentle, wide slope on the abapical side, respectively. Quirinii type ridges occur both in Wortheniopsis and Foveolaria n. gen. but differently distributed on the shells of these taxa; it suggests possible phylogenetical relationship of these two genera and, at the same time, is suitable to help their distinction.

Turbo quirinii has similar shape and ornament to Wortheniopsis margarethae, therefore KITTL (1899) placed them into the same genus. However, as the available information indicates, Turbo quirinii has a sinuszone and significantly different shape of the growth lines while the type species of Wortheniopsis seems to have a selenizone, therefore tracing for their accurate relations and systematic place must be continued.

Since the original shell structure, the protoconch, the earliest and the latest teleoconch parts have not yet found preserved, no higher systematic arrangements are supported sufficiently. Beside this type of uncertainties, recent

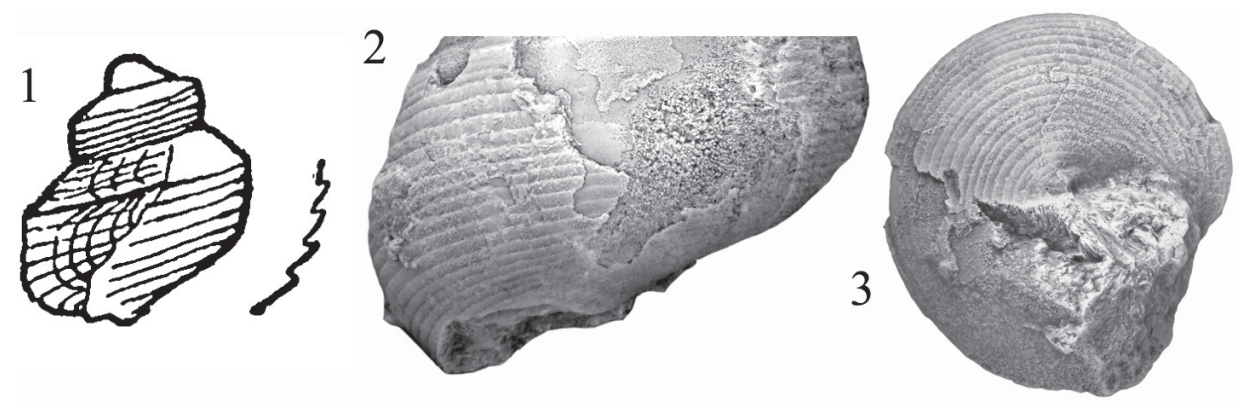

Figs 1-3. The peculiar "quirinii type" ridges, occurring in Wortheniopsis Böhm, 1895, Foveolaria n. gen. and some probably related forms. - 1. Copy of Kitru's (1899, p. 14, Fig. 2) sketch. - 2. The ridges on the outer face and on the base of Wortheniopsis rakusi n. sp. -3 . The ridges on the base of Foveolaria conoidea n. sp. 
suggestions for the phylogenetic relations and classification (WAGNER 2002; BoUCHET et al. 2005; FRÝDA et al. 2008) are also full of uncertainties. Actually, class Gastropoda is the only doubtless higher taxon in the systematic part below. The early opinions (KITTL 1894, 1899; BöнM 1895) about the relations of Wortheniopsis referred to Worthenia that is reflected also in Wenz's (1938) classification (Pleurotomariidae, Lophospirinae). Subsequently, Knight, Batten and Yochelson (in KNIGHT et al. 1960) placed it into Plethospiridae (Pithodeinae). Since WAgNer (2002) concluded that Plethospira represents an evolutionary "dead end" and the other members of the family are not closely related, the opinion from Vostokova in PCHelincev \& Korobkov (1960), giving family status to Pithodeinae, is followed here tentatively.

Class Gastropoda Cuvier, 1797

?Order Archaeogastropoda Thiele, 1925

?Suborder Murchisoniina Cox et Knight, 1960

?Superfamily Murchisonioidea Koken, 1896

?Family Pithodeidae Wenz, 1938

Genus Wortheniopsis J. Böhm, 1895

Type species - Pleurotomaria margarethae Kittl, 1894, Marmolada Limestone, Ladinian (Middle Triassic)

Emended diagnosis - Moderately high turbiniform to subconoidal, thin walled shells of convex whorls. Earliest shell parts unknown. Suture variably impressed. Surface of early whorls evenly arched, later whorls having obscure spiral angulation adapically from midwhorl. Flat to concave ramp between upper suture and angulation. Flat or feebly concave selenizone between two spiral threads, abapical one just overlapping ridge of angulation. Feebly concave to feebly convex outer face, being wider than ramp. Transition from outer face to base widely and evenly arched. Base subglobose as whole with convex wall, anomphalous or narrowly phaneromphalous. Aperture rounded with angle at terminus of suture. Thin, smooth shell layer representing parietal lip; columellar/umbilical lip vertical, thin or weakly thickened. Ornament of spiral and collabral threads and granules on whorls, threadlike spiral ridges of asymmetric triangle cross-section on base and on outer face (quirinii type ridges). Growth lines feebly prosocline and fairly prosocyrt on both sides of selenizone, respectively, feebly opisthocline and opisthocyrt on base.

Remarks - All syntypes of Wortheniopsis margarethae are of very poor preservation, therefore the nature of the exhalant system, critical for classification, has remained debatable for the recently active researchers of the Triassic gastropods. The original descriptions and drawings do not provide satisfactory help 
to see doubtlessly if the type species has a slit and selenizone or only peristomal sinus and sinuszone on the whorls. Therefore a re-study of the specimens has become necessary for further discussion.

The restudy of the syntypes (NHMV 1969/1103) has confirmed, as their figures (KITTL 1894, Pl. VI, Figs 1-3) also show, that even the best preserved syntype of the type species bears only very small pieces of badly worn shell fragments on inner mould and their outermost layer is lacking. Actually, the lines of the ornament are much more obscure than the drawings show them. A narrow, smooth and flattish ribbon between two eroded spiral threads represents the anal fasciole just adapically from an obscure angulation of the whorl surface, aligned to the abapical spiral thread. Some distinct lines of KitTL's drawing (1894, Pl. VI, Fig. 2) show that the growth lines of the subsutural ramp and those of the outer face form a sharp angle at the ridge of the obscure angulation i.e. at the abapical spiral thread. Actually, those few lines that cross the belt between the two spiral threads are straight linear damages and are not aligned to the growth-lines. Waste majority of the collabral lines terminate at or before reaching the two spiral threads, limiting the smooth belt that must be therefore a selenizone. The selenizone is smooth like in the latest growth phases of the two new Jurassic species.

Similarly to Pleurotomaria margarethae, Turbo quirinii Stoppani, 1858 and Turbo funiculatus Stoppani, 1858 occurred in the same formation, the Marmolada Limestone (Ladinian, Middle Triassic). First Mariani (1896) then KITTL (1899) regarded these species also as Wortheniopsis. The latter author has also unified the two latter species, however, as KITTL (1899, Pl. 14-15) figures show it, the interpretation of this species involves so significantly different morphologies that it might belong to two species.

According to unpublished data of S. Monari (Padua University), slitless, sinuszone bearing gastropod with morphology similar to the type species of Wortheniopsis occurs in the fauna of the Marmolada Limestone (MONARI, pers. comm.).

The Late Triassic Wortheniopsis budensis Kutassy, 1927, in lack of any traces of the exhalant system, is excluded from the comparisons. The name Wortheniopsis has also been applied to some Palaeozoic forms but their revision is out of the scope of this paper.

The emended diagnosis above is based on the study of the syntypes of the type species, Pleurotomaria margarethae Kittl, 1894 and monotypes of two new Jurassic species, Wortheniopsis rakusi n. sp. and Wortheniopsis bakonyensis n. sp. The morphology of these three species is similar to each other so they seem to be closely related. 
The morphology of the growth lines in the new specimens permits to reconstruct elements of the outer lip that has not yet been found in preserved form. It is just very feebly prosocline, almost orthocline as a whole and composed of prosocyrt parts at both sides of the selenizone, respectively, and feebly opisthocyrt on the base. The growth lines meet the selenizone in $50-60^{\circ}$ angles at its both sides. It probably means that the rim of the outer lip is angular at both sides of a peristomal fissure, like in Scissurellidae. This morphology is different in Pleurotomarioidea where a wide, strongly prosocline-prosocyrt growth line belt is characteristic adapically from the selenizone, prosocyrt and narrow belt between the base and the selenizone, and markedly parasigmoidal on the base. Furthermore, these growth lines asymptotically approach the selenizone, i.e. the rim of the peristome is widely arched at both sides of the slit. These differences support the non-pleurotomarioidean systematic position for Wortheniopsis. The sinus-bearing counterpart ("Turbo" quirinii Stoppani) in the Middle Triassic seems to represent an earlier evolutionary stage, and suggests belonging to one of the archaic higher taxa. Although similar situation occurs also in some other family rank taxa, e.g. in Raphistomatidae, containing also genera of similar shell morphology, tentatively Pithodeidae is selected as family position for Wortheniopsis.

Distribution - Beside the Alpine Middle Triassic (Marmolada Limestone) here verified in the Lower Jurassic (Hierlatz Limestone).

Wortheniopsis rakusi n. sp.

(Figs 4-10)

Type specimen - GBA 2017/001/0002.

Type locality - Hierlatz Alpe, Hallstatt (Austria).

Type strata - Sinemurian to lowermost Pliensbachian (Lower Jurassic) Hierlatz Limestone.

Derivation of name - Dedicated to Milos Rakús, late Slovakian colleague.

Material - Single specimen that consists of four fragmentary whorls; protoconch and the earliest teleoconch whorls are lacking, just like the latest, near peristome parts of the last whorl.

Dimensions - Width: $11.5 \mathrm{~mm}$; spiral angle: $45^{\circ}$.

Diagnosis - High turbiniform, thin walled shell; slightly convex whorls, shallow impressed suture, last whorl somewhat inflated. Early whorls roundedangular at both sides of suture, last whorl turning into base along wide, even arch. Last whorl with obscure angulation and slightly concave ramp below adapical suture. Base as whole subconoidal, its wall convex; ?narrowly phaneromphalous. Selenizone rather narrow, concave and bordered by two threads above midwhorl 
on latest whorls. Ornament of spiral threads above selenizone, crossed by collabral threads with granules at intersecting points. Sparse, asymmetrical, weak spiral ridges below selenizone and on base. Growth lines fine, prosocyrt and just gently prosocline above and below selenizone on whorls, feebly opisthocline on base with shallow opisthocyrt part abaxially. Selenizone with sparse lunulae on early whorls, with growth lines only on last whorl.

Description - A high turbiniform, very thin walled shell represents the species. It is composed of slightly convex whorls, which are separated by a slightly impressed, almost flush suture. The earliest preserved whorls are rounded-angular at both sides of the suture but the last whorl turns into the base without angulation along a wide, even arch. The spire whorls are slightly convex and there is no angulation on their surface but the belt between the selenizone and the adapical suture becomes feebly concave on the last whorl; actually a concave ramp develops. Along the abapical boundary of the ramp, which coincides with the abapical rim of the selenizone, an angulation with the outer face is just observable. The selenizone itself seems flat on the early whorls but concave on the last one; its width is rather narrow, about $12 \%$ of the sutures distance on the penultimate whorl. The outer face itself is wider than the ramp and has flat surface that bends into the base along a wide, unbroken arch. The base is convex, subconoidal as a whole and it has convex wall that evenly turns into an axial deepening. Its matrix infilling seems to hide a narrow umbilicus. The selenizone is narrow, concave and two threads border it well above the midwhorl on all preserved whorls.

Several equally spaced spiral threads ornament the whole surface adapically from the selenizone that are crossed by collabral threads and granules are at their intersecting points. Towards the last whorl, the number of the growth lines increases. Sparse, asymmetrical, weak spiral ridges, belonging to the type which has been first observed in Wortheniopsis quirinii (Stoppani, 1858), see in KITTL (1899, p. 14, Fig. 2.), ornament the whorls below the selenizone and on the base. Lunulae are present on the selenizone of the early whorls but they are missing on the last whorl. The growth lines are very fine and have a peculiar arrangement; they are prosocyrt and just gently prosocline above and below the selenizone on the whorls and feebly opisthocline on the base with a shallow opisthocyrt part on the abaxial half of the base.

Remarks - The only specimen of Wortheniopsis rakusi n. sp. is exceptionally well preserved compared to the syntypes of the Middle Triassic type species. In spite of the considerable age difference, their comparison shows only slight differences in the shell shape and the details of the ornament. $W$. rakusi n. sp. has about $10^{\circ}$ wider spiral angle, less impressed suture, less convex whorls, so more conoidal outline, and a network ornament with granules at the crossings between the selenizone and the adapical suture. 


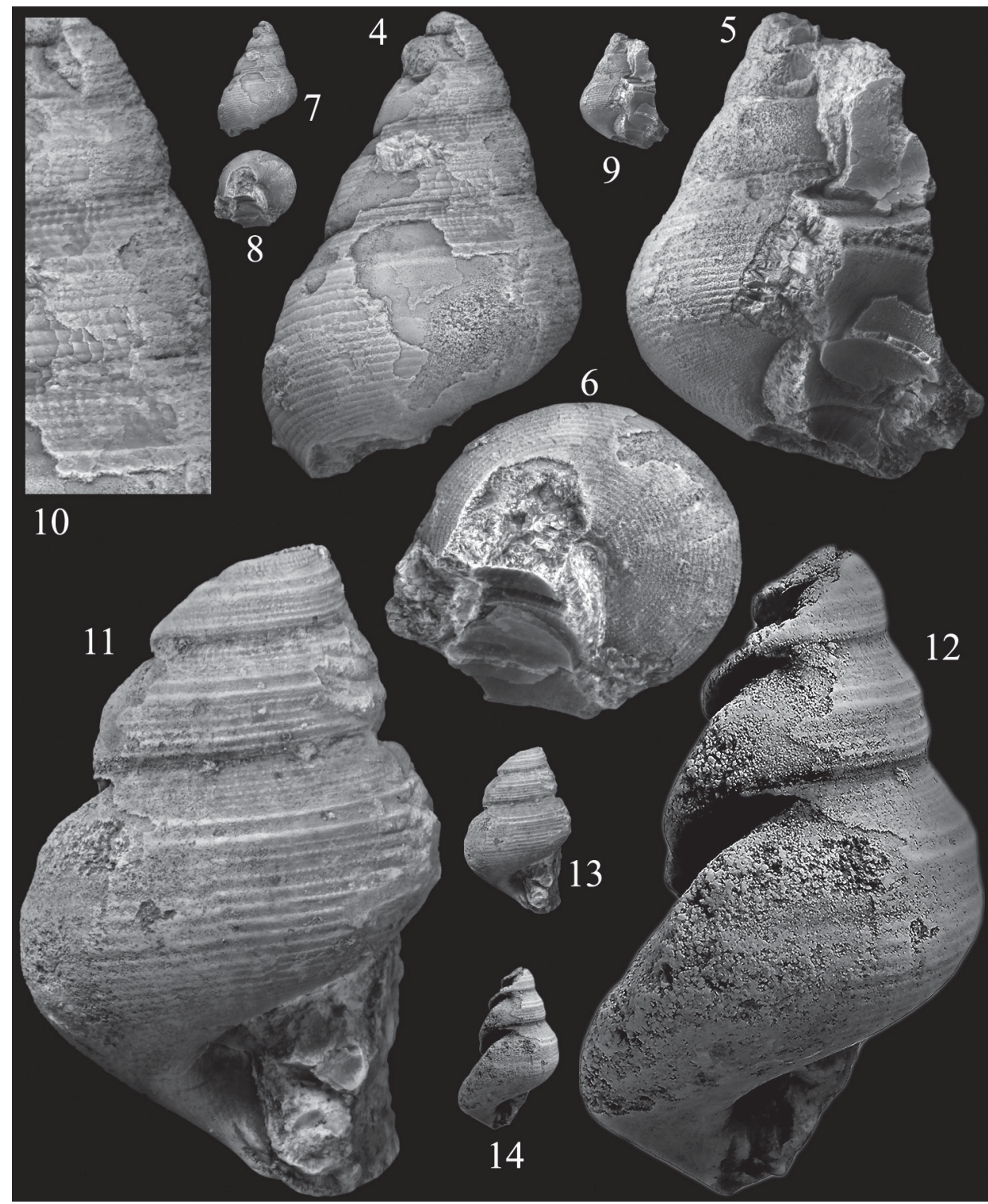

Figs 4-14. Wortheniopsis species from the Hierlatz Limestone Formation. -4-10. Wortheniopsis rakusi n. sp. from the Sinemurian to lowermost Pliensbachian interval (Lower Jurassic) of the Hierlatz Limestone in the Hierlatz Alpe, Hallstatt, Austria, GBA 2017/001/0002, all ×4. - 4. Dorsal view. - 5. Peristomal view. - 6. Basal view. - 7-9. Same views as 4-6 but in natural $(\times 1)$ size. -10 . Details of the ornament on the spire whorls, $\times 7$. - 11-14. Wortheniopsis bakonyensis $\mathrm{n}$. sp., ?Lower Sinemurian (Lower Jurassic) Hierlatz Limestone variety with rich micrite content, Csárdahegy, Úrkút, Bakony Mts, Hungary, GGIH J.08.3.1. - 11. Peristomal view of the holotype, $\times 4$. -12 . Lateral view to show the best preserved outline part, $\times 4$. $-13-14$. The same views as in figures $11-12$ but in natural $(\times 1)$ size 
$W$. rakusi n. sp. clearly shows that the growth lines and the collabral ornamental elements terminate at the threads, delimiting the anal fasciole, which indicate a true selenizone, not a sinuszone. Lunulae on the penultimate whorl and lunuliform growth lines on the last whorl endorse this assumption. Both species have quirinii type ridges between the selenizone and the axial region of the base.

For distinction from Wortheniopsis bakonyensis n. sp. see the next description.

Distribution - Within Sinemurian to lowermost Pliensbachian (Lower Jurassic) part of the Hierlatz Limestone Formation in Hierlatz Alpe, Hallstatt, Austria.

Wortheniopsis bakonyensis n. sp.

(Figs 11-14)

2009 Wortheniopsis (Wortheniopsis) aff. procera (J. A. Eudes-Deslongchamps, 1849) - SzABó, p. 29,

Fig. 22.

Type specimen - GGIH J.08.3.1.

Type locality - Csárdahegy, Úrkút, Bakony Mts (Hungary).

Type strata - Lower? Sinemurian (Lower Jurassic) Hierlatz Limestone variety with relatively rich micrite content.

Derivation of name - Referring to the wider surroundings of the locality, the Bakony Mts.

Material - Single specimen that consists of three partial whorls; the earliest whorls and the near-peristome parts are fully lacking.

Dimensions - Width: $14 \mathrm{~mm}$; spiral angle: $50^{\circ}$.

Diagnosis - Ramp flat and steep, outer face concave; earlier whorls roundedangular above suture, last whorl evenly rounded toward base. Concave selenizone between two sharp ridges, abapical one just overlapping angulation of whorl surface. Base subconoidal as a whole with slightly convex wall; moderately broad umbilicus with rounded-angular rim. Umbilical lip seeming subvertical. Spiral ornament on full shell surface, excepting selenizone, threads on ramp, quirinii type ridges on outer face and base, all finely granulated even within umbilicus. Collabral threads observable on ramp.

Description - The shell is high turbiniform, extremely thin walled with slightly convex whorls that have an angulation above the midwhorl. The ramp is feebly concave on the earlier whorls but flat on the last whorl. The selenizone is slightly protruding from its environs and it is fairly concave on all whorls; its position is on the ramp just along the angulation. Abapically, a concave outer whorl face limits the selenizone, which is wider than the ramp and rounded-angular above the suture; this angulation is more marked on the earlier whorls and widely rounded, practically absent on the last whorl. The suture appears deeply 
impressed since it is built somewhat adaxially from the periphery of the whorls. The base is subconoidal with slightly convex wall and a moderately wide umbilicus, having a rounded-angular rim. Remnants suggest subaxial orientation of the umbilical lip and no trace of the parietal lip has been found; no more information, concerning the peristome is preserved.

All whorls are covered by spiral ornament, except the selenizone. It consists of spiral threads on the ramp and quirinii type ridges on the outer face and the base. Weak collabral threads are observable on the ramp and the outer face of the earliest whorl with granules at the crossings with the spiral threads. The collabral threads of the ramp are vanishing only on the last whorl but lacking already from the outer face of the penultimate whorl. However, the granules remain present also on the spiral threads and ridges of the latest shell parts, even on the base and within the umbilicus. The growth lines and the collabral ornament are feebly prosocline and clearly prosocyrt on both sides along the selenizone. The growth lines of the base are nearly orthocline and somewhat opisthocyrt.

Remarks - Granules of the spiral ridges on the base are almost fully removed by erosion, however some remnants indicate in strong magnification that they are present on all ridges.

Wortheniopsis bakonyensis n. sp. differs from $W$. rakusi n. sp. in having the angulation of the whorl surface from a much earlier growth stage; i. e. all whorls (3) are angulated in $W$. bakonyensis but only the last one in $W$. rakusi. It means also that a ramp has developed only on the last whorl of $W$. rakusi while in $W$. bakonyensis it is present (at least) two whorls earlier. W. bakonyensis has feebly concave outer face on all preserved whorls but W. rakusi has flat outer face on the last whorl and feebly convex corresponding belt on the former whorls. In $W$. rakusi, no granulation is present neither on the outer face nor on the base.

Distribution - Lower? Sinemurian Hierlatz Limestone, Csárdahegy, Úrkút, Bakony Mts, Hungary.

\section{Genus Foveolaria n. gen.}

Type species - Wortheniopsis (Sisenna) lokutensis Szabó, 2009.

Derivation of name - Foveola (Lat.) $=$ small hole, alluding to Pleurotomaria foveolata J. A. Eudes-Deslongchamp, 1849, the earliest species name for a group of species, included here to Foveolaria n. gen.

Diagnosis - Turbiniform to conoidal or coeloconoidal, thin-walled shells of slightly convex whorls, being obscurely to clearly angular in latest growth stages. Base convex, narrowly phaneromphalous, some possibly anomphalous. Slit rather long, selenizone concave or flat between two threads at or below midwhorl as abapical belt of ramp or blunting angulation of whorl surface. Outer 
whorl face more or less concave. Abaxial rim of base angular, reinforced by cord or swollen belt, providing periphery. Apex blunt, protoconch low with evenly convex whorls. Ornament consisting of collabral riblets and spiral threads in high variability of patterns; granules frequently occurring at crossing points. Lunulae mostly on early selenizone. Growth lines delicate, more prosocline and prosocyrt adapically from selenizone, feebly prosocline to opisthocline abapically; prosocline and slightly opisthocyrt on base.

Description - Shells of Foveolaria approach turbiniform to conoidal shape with more or less gradate outline and variable spire height. They are very thinwalled, the early teleoconch whorls are simply convex but the latest whorls become obscurely to markedly angular at or below the midwhorl. The protoconch is poorly known; it has depressed turbiniform shape in the type species with evenly convex whorls and rather deeply impressed suture. The suture remains more or less impressed also along the subsequent whorls. The last whorl meets the base in a more or less rounded angulation that is reinforced by a swollen spiral belt or cord. The base as a whole has subconoidal to subglobular shape with feebly to strongly convex wall. In most species, a narrow phaneromphalus is observed; in some cases absence of the umbilicus seems probable. The slit is rather long as it is demonstrated by the only photo available (FISCHER \& WeBER 1997, Pl. 25, Fig. 12), it extends about $60^{\circ}$ abaperturally. The selenizone is mostly concave or rarely flat between two threads at or, more commonly, somewhat below the midwhorl. Usually, it lies as abapical belt within the plane of the ramp and its abapical thread coincides with the ridge of angulation of the whorls but less frequently, it forms a third surface of the whorls, which blunts the angulation between the ramp and the outer face. Width of the selenizone is around $15 \%$ of the distance between two neighbouring sutures. In some species, the limiting threads are lacking or substituted by shallow striae on the last whorl. Outer face of the whorls is flat to concave and nearly parallel to the coiling axis; usually, its abapical rim corresponds to the periphery.

The ornament is composed of collabral riblets and spiral threads in high variability of patterns, frequently combined with granules and/or short riblets between pairs of spiral ridges at the crossing points. The short riblets are usually aligned collabrally forming false threads. Quirinii type ridges are also developed usually only on the base and mainly in the stratigraphically older (Sinemurian) species; rarely they occur also on the abapical part of the outer face. Lunulae occur mostly on the early selenizone parts, rarely present also on latest whorls. The growth lines are delicate, clearly prosocline and prosocyrt adapically from the selenizone but slightly prosocline to opisthocline and prosocyrt between the selenizone and the periphery, slightly prosocline and feebly opisthocyrt on the base. 
Remarks - The shell form and many details are similar in Wortheniopsis and Foveolaria. Most reliable distinctive characters are the position of the selenizone, the orientation and shape of the growth lines (outer lip), the width of the outer face and the distribution of the quirinii type ridges on the shells. The selenizone is above the midwhorl in Wortheniopsis but at/or below the midwhorl in Foveolaria. Consequently, the width of the outer face is significantly narrower in Foveolaria than in Wortheniopsis. The growth lines (outer lip) are almost orthocline, just feebly prosocline in Wortheniopsis but clearly prosocline in Foveolaria in the belt adapically from the selenizone. The quirinii type ridges appear between the abapical edge of the selenizone and the axial region of the base in Wortheniopsis, however, they are present mostly on the base or, mainly in stratigraphically younger species, substituted by simple spiral threads in Foveolaria. In few cases, they are recognisable also on the outer face in strongly modified form, e.g. in $F$. hierlatzensis (Szabó, 2009) or in F. kocsisi n. sp., with short riblet-like granules, rapidly diminishing abapically before reaching the next spiral ridge.

In common cases, the selenizone is the abapical belt of the ramp in Foveolaria, however, in some species, the selenizone does not lie in the plane of the ramp but blunts the angulation of the whorl surface like e.g. in Foveolaria conoidea n. sp. or Foveolaria globosa n. sp. (see below). If the selenizone is not clearly concave, like in Foveolaria hierlatzensis (Szabó, 2009), these forms may recall the shape of Bathrotomaria Cox, 1956. However, in the latter genus, the selenizone is clearly convex, its adapical belt is part of the ramp and the abapical part belongs to the outer face, i.e. the selenizone itself is also mostly angular.

Species - With the name Pleurotomaria foveolata, J. A. Eudes-DeslongCHAMPS (1849) covered six different but doubtlessly related shell forms that he regarded as varieties (trochoidea, subturrita, turrita, procera, pinguis and ellipsoidea). D'OrBIGNy (1854) raised these varieties, with some modifications, to species rank with indication of own authorship: Pleurotomaria subturrita, $P$. pinguis, $P$. ellipsoidea, $P$. subfaveolata, $P$. procera. The name subturrita in d'Orbigny's interpretation contains also var. turrita J. A. Eudes-Deslongchamps; the name subfaveolata is given instead of var. ellipsoidea J. A. Eudes-Deslongchamps. By the ICZN (1999) rules, the true author of these species names is J. A. Eudes-Deslongchamps, except subfaveolata, and the original species name (foveolata) becomes a nomen nudum. This name remains applicable only if a reviser (1) rejects any subdivision, or (2) reduces the rank of the varieties as FISCHER \& WEBER (1997) have done it; in their species interpretation the former varieties are treated as "morphes". In either cases lectotype or neotype selection is necessary like in FISCHER \& Weber (1997). Following the arguments in Szabó (2009, p. 28), J. A. EudesDeslongCHAMPS (1849) varieties are treated as species also in this paper but without a deep revision. 
Foveolaria trochoidea (J. A. Eudes-Deslongchamps, 1849), p. 73, Pl. XV, Figs 2a, b. Foveolaria subturrita (J. A. Eudes-Deslongchamps, 1849), p. 73, Pl. XV, Figs 3a, b. Foveolaria turrita (J. A. Eudes-Deslongchamps, 1849), p. 74, Pl. XV, Figs 4a, b. Foveolaria procera (J. A. Eudes-Deslongchamps, 1849), p. 74, Pl. XV, Figs 5a, b. Foveolaria pinguis (J. A. Eudes-Deslongchamps, 1849), p. 75, Pl. XV, Figs 6a, b, c. Foveolaria ellipsoidea (J. A. Eudes-Deslongchamps, 1849), p. 75, Pl. XV, Figs 7a, b. Foveolaria urkutensis (Szabó, 2009), p. 29, Figs 23A-E.

Foveolaria hierlatzensis (Szabó, 2009), p. 30, Figs 24A-F.

Foveolaria jancsii (Szabó, 2009), p. 31, Figs 25A-P.

Foveolaria lokutensis (Szabó, 2009), p. 32, Figs 26A-E.

Foveolaria bicarinata n. sp.

Foveolaria conoidea n. sp.

Foveolaria globosa n. sp.

Foveolaria suemegensis n. sp.

Foveolaria kocsisi n. sp.

Foveolaria sp.

Distribution - Sinemurian to Pliensbachian (Jurassic) in deposits of the Western Tethys and the Western European epicontinental seas.

Foveolaria bicarinata n. sp.

(Figs 15-18)

Type specimen - GBA 2017/001/0003.

Type locality - Hierlatz Alpe, Hallstatt (Austria).

Type strata - Within Sinemurian to lowermost Pliensbachian (Lower Jurassic) Hierlatz Limestone.

Derivation of name - Bicarinata (Lat.) = having two ridges; referring to the sharp spiral angulations, limiting the concave outer face of the whorls.

Material - Single fragmentary specimen with remnants of three whorls that are characteristic enough to outline a new species.

Dimensions - Width: $12.2 \mathrm{~mm}$.

Diagnosis - Gradate, medium high shell of whorls with rather steep ramp and concave outer face with sharply angular edges, abapical one providing periphery. Base low, subglobose as whole with moderately convex wall; phaneromphalous, umbilical rim rounded angular. Suture rather deeply impressed, running somewhat adaxially from periphery of former whorl. Ramp ornamented by regularly repeating collabral riblets; outer face with single thin thread above midline and some obscure striae above it. Below peripheral sharpness, another but weaker keel visible, remaining parts of base covered by quirinii type spiral ridges. Selenizone bearing lunulae on earlier whorls, gradually vanishing on last whorl. 
Description - A gradate, medium high shell is available; its reconstructed height is about $20 \mathrm{~mm}$. The whorls have rather steep ramp that is slightly convex on the earlier whorls but flat on the last whorl. At its abapical edge, the spiral angulation is marked, sharp keel-like on the last whorl but less prominent, slightly rounded on the earlier shell parts. A strong spiral thread gives the adapical boundary for the selenizone that is concave. The outer face is markedly concave with an abapical edge that is also sharply angular. This ridge corresponds to the periphery. The base is low, subglobose as a whole and has moderately convex wall; it is rather broadly phaneromphalous and has a rounded angular umbilical rim. Near the peripheral angulation, a weaker keel also develops on the base; the suture is seamed about halfway between these two keels, so the suture is rather deeply impressed.

Regularly repeating collabral riblets ornament the ramp, they start at the adapical suture, and with gradual weakening, terminate at the rim of the selenizone. On the ramp, no spiral ornament is observable on the preserved shell fragment. The outer face bears a single thin thread above the midline and some obscure striae are also visible above it. Between the weak keel of the base at the peripheral belt and the umbilicus, quirinii type spiral ridges represent the ornament. They are denser in the abaxial half than in the remaining part of the base. The selenizone bears lunulae on the earlier whorls that gradually vanish on the last whorl. The growth lines are strongly prosocline on the ramp with markedly prosocyrt subsutural and feebly prosocyrt remaining parts; on the outer face, the growth lines are feebly prosocline and clearly prosocyrt. The growth lines of the base are more prosocline $\left(\sim 45^{\circ}\right)$ than it is common in Foveolaria $\left(\sim 30^{\circ}\right)$, and they are somewhat more opisthocyrt than it is usual.

Remarks - Foveolaria bicarinata n. sp. resembles F. suemegensis n. sp. (see below) in the keel like angulations on the whorl surface and at the periphery, limiting a markedly concave outer face. The latter species has higher, somewhat acute spire, much widely developed and steeper ramp. Moreover, F. suemegensis has only barely developed or obscure spiral ornament on the latest whorls, while F. bicarinata bears few but clear spiral threads and sharp collabral riblets. Their dimensions are also significantly different.

Distribution - Within the Sinemurian to lowermost Pliensbachian interval (Lower Jurassic) of the Hierlatz Limestone Formation in Hierlatz Alpe, Hallstatt, Austria.

Foveolaria conoidea n. sp.

(Figs 19-22)

Type specimen - GBA 2017/001/0004.

Type locality - Hierlatz Alpe, Hallstatt (Austria). 
Type strata - Sinemurian to lowermost Pliensbachian (Lower Jurassic) Hierlatz Limestone.

Derivation of name - Referring to the conoidal shell outline.

Diagnosis - Conoidal shell outline with slightly convex whorls with obscure angulation feebly below midwhorl. Ramp flattish with narrow convex belt subsuturally and concavity along selenizone. Selenizone concave and angled to ramp and outer face so blunting angulation of whorl. Outer face concave, limited by markedly swollen abapical belt, providing periphery of shell and rim of base. Base low conoidal as whole and having slightly convex wall; anomphalous or minutely phaneromphalous. Spiral threads and collabral riblets on whorls except in selenizone, spiral ones vanishing from later whorl. Base covered with almost evenly spaced quirinii type ridges.

Material - Single specimen, composed of remains of three latest whorls.

Dimensions - Width: $9.4 \mathrm{~mm}$.

Description - The only shell has conoidal, just slightly gradate outline with an obscure angulation feebly below the midwhorl. The rather steep ramp is flattish with a narrow convex belt subsuturally and some concavity along the selenizone. The selenizone itself is concave and angled both to the ramp and the outer face obscuring the angulation of the whorls. The outer face is concave; a markedly swollen belt limits it abapically, providing also the periphery of the shell and outer rim of the base that joins with angulation to the whorl surface. The slightly impressed suture does not follow the periphery but a line slightly adaxially from it on the base. As a whole, the base is low conoidal with slightly convex wall; the shell is anomphalous or minutely phaneromphalous.

Spiral threads and collabral ribs/riblets ornament the whorls apart from the selenizone; granules at the intersections are frequently preserved. The spiral threads are sparse and much weaker than the ribs on the ramp and gradually vanish for the last growth phase. The ribs of this area start from the suture and almost vanish before reaching the selenizone; their subregularly repeated interspaces gradually increase on the last half whorl. On the outer face, spiral and collabral threads form a dense network; first the collabral ones change into short riblets, crossing the spiral threads, then they fully disappear for the last

Figs 15-29. New species of Foveolaria n. gen. from the Sinemurian to lowermost Pliensbachian interval (Lower Jurassic) of the Hierlatz Limestone in the Hierlatz Alpe, Hallstatt, Austria. - 15-18. Holotype of Foveolaria bicarinata n. sp., GBA 2017/001/0003, all ×3.8. - 15. Dorsal view. - 16. Apical view. - 17. Basal view. - 18. Peristomal view. - 19-22. Holotype of Foveolaria conoidea n. sp., GBA 2017/001/0004, all ×4. - 19. Dorsal view. - 20. Apical view. - 21. Basal view. - 22. Peristomal view. - 23-26. Holotype of Foveolaria globosa n. sp., GBA 2017/001/0005, all ×4. - 23. Dorsal view. - 24. Apical view. - 25. Basal view. - 26. Peristomal view. - 27-29. Foveolaria sp., GBA 2017/001/0006, all ×4. - 27. Apertural view. - 28. Basal view. - 29. Dorsal view 


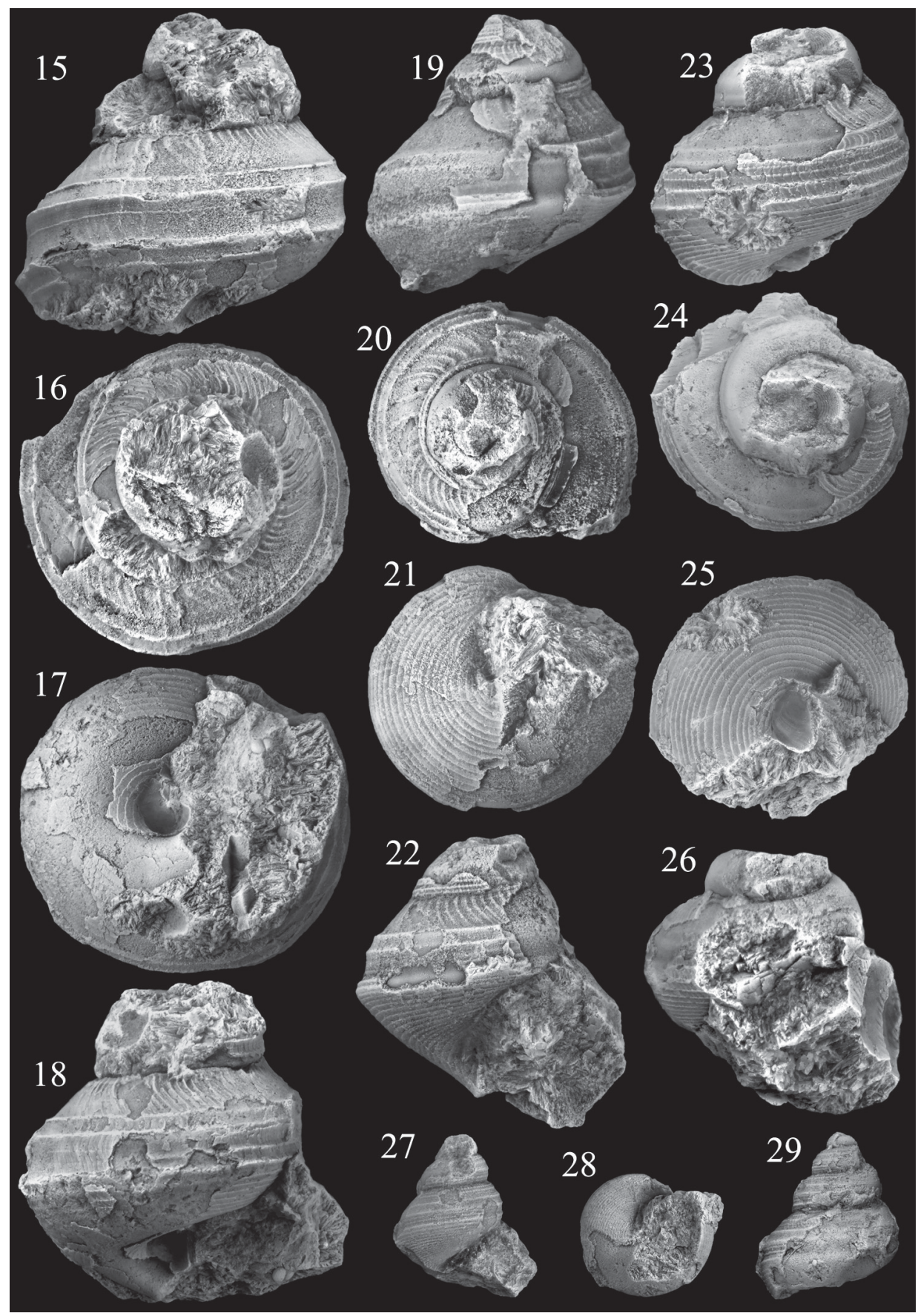


whorl. The spiral threads also vanish from the adapical belt of the outer face but remain in the swollen peripheral belt. On the selenizone of the preserved shell parts, no lunulae are found. The base is covered with almost evenly spaced moderately dense quirinii type ridges. The growth lines are rather strongly prosocline and prosocyrt on the ramp, prosocyrt-orthocline on the outer face and slightly prosocline-opisthocyrt on the base.

Remarks - The vanishing ornament of the latest whorl resembles the last whorl of Foveolata bicarinata n. sp. The steeper ramp, the less impressed suture, consequently less gradate outline, and the selenizone, blunting the angulation of the whorl surface distinguish Foveolaria conoidea n. sp. from F. bicarinata. Besides, the latter species has a rather broad umbilicus but $F$. conoidea seems anomphalous or very narrowly phaneromphalous.

The subglobular shell, the more convex surfaces (ramp, outer face and base wall) and the presence of a quite wide umbilicus in Foveolaria globosa n. sp. distinguish it from $F$. conoidea.

Foveolaria suemegensis $\mathrm{n}$. sp. has similarly steep ramp like $F$. conoidea but their ornaments at identical size are strongly different; marked in F. conoidea but scarce in F. suemegensis. Their selenizones are also in different position.

Distribution - Within the Sinemurian to lowermost Pliensbachian interval (Lower Jurassic) of the Hierlatz Limestone Formation in Hierlatz Alpe, Hallstatt, Austria.

Foveolaria globosa n. sp.

(Figs 23-26)

Type specimen - GBA 2017/001/0005.

Type locality - Hierlatz Alpe, Hallstatt (Austria).

Type strata - Sinemurian to lowermost Pliensbachian (Lower Jurassic) Hierlatz Limestone.

Derivation of name - Globosa (Lat.) = globular; referring to the last whorl of the shell, providing the shell with subglobular shape.

Diagnosis - Subglobular shell with rounded whorls; both usual angulations of Foveolaria obscure. Selenizone blunting angulation at abapical rim of ramp, flat-convex outer face hiding other one at outer rim of base. Base subglobular with strongly convex wall and rather broad umbilicus. Ornament of collabral riblets and thin spiral threads on ramp, lunulae between strong limiting threads of selenizone, strong spiral threads on outer face, crossed by thin collabral threads, vanishing in abaxial belt of base. Base covered by quirinii type ridges. Growth lines prosocline-prosocyrt on ramp, prosocline-feebly prosocyrt on outer face and prosocline-feebly opisthocyrt on base. 
Material - Single, damaged specimen of two whorls.

Dimensions - Width: $9 \mathrm{~mm}$.

Description - Both angulations of the latest whorls, common in Foveolaria, are obscure on the available specimen, therefore the whorls have almost evenly arched surface. A rather wide selenizone is blunting the adapical angulation at the abapical rim of the ramp, and the flat-convex outer face almost fully hides also the second angulation at the outer rim of the base but the strongest spiral cord somewhat highlights it and gives the periphery. On the earlier whorl, this angulation is still clearly visible above the suture, which is impressed. The base itself is subglobular with a strongly convex wall and a rather broad phaneromphalus.

The ornament of the ramp on the last whorl in the available specimen consists of marked collabral riblets, which are equally strong along their full length and thin, dense spiral threads. Regularly repeating lunulae are present in the selenizone between strong boundary threads. Few (4) marked spiral threads are visible on the outer face; their strength increases and their interspaces widen in abapical direction. The strongest thread provides the periphery and the outer rim of the base; the suture is positioned slightly adaxially from this thread. The outer face is crossed by thin collabral threads, vanishing within the abaxial belt of the base; tiny granules are in the intersections. Quirinii type ridges cover the base. The growth lines are prosocline-prosocyrt on the ramp, prosocline-feebly prosocyrt on the outer face and prosocline-feebly opisthocyrt on the base.

Remarks - Two rounded angulations do not occur on late whorls of the shell in other species. The most similar, rather globose species is Foveolaria pinguis (J. A. Eudes-Deslongchamps, 1849) as figured by Fischer \& WEBER (1997) but its angulations and a subvertical outer face are present also on the latest whorl, furthermore, it has an ornament of granulate riblets, denser than in Foveolaria globosa n. sp.

The lack of globosity in the species, discussed in this paper, well distinguishes them from F. globosa, however, further details are added also in their descriptions.

Distribution - Within the Sinemurian to lowermost Pliensbachian interval (Lower Jurassic) of the Hierlatz Limestone Formation in Hierlatz Alpe, Hallstatt, Austria.

\section{Foveolaria kocsisi n. sp.}

(Figs 30-31)

1980 Sisenna pinguis (Deslongchamps, 1849) - SzABó, p. 53, Pl. I, Fig. 1.

2009 Wortheniopsis (Sisenna) aff. hierlatzensis Szabó, 2009 - SzABó, p. 34, Fig. 27C, D.

Type specimen - GGIH J.08.9.1.

Type locality - Kericser-dülő, Lókút, Bakony Mts (Hungary). 
Type strata - Beds with Obtusum to Ibex Zones (Upper Sinemurian to Lower Pliensbachian, Jurassic) mixed fauna in Hierlatz Limestone.

Derivation of name - Dedicated to Lajos Kocsis (Sümeg), leader worker of the collecting staff at the type locality.

Diagnosis - Gradate shell with whorls of flattish concave ramp and concave outer face. Suture impressed, running slightly below periphery. Base subglobular with convex wall and no or only narrow umbilicus. Concave selenizone between sharp threads. Ornament consisting of network from spiral and collabral threads with granules at intersection points on ramp and adapical part of outer face. Quirinii type spiral ridges on abapical belt of outer face and on base with short, riblet-like granules, aligned into seemingly continuous collabral threads.

Material - Two fragmentary specimens, one is shelly, the other is an inner mould with small shell fragments.

Dimensions - Preserved height: $11 \mathrm{~mm}$; preserved width: $10 \mathrm{~mm}$.

Description - The shells are gradate with clearly angulate whorls. The ramp is flattish but slightly convex just below the suture; its abapical rim is concave along the selenizone. The selenizone itself is moderately wide, concave between two sharp spiral cords; the abapical one just coincides with angulation of the whorl surface. The outer face is rather wide and its surface is nearly parallel to the axis but having also a feebly concave median belt. Its lower edge is slightly swollen next the rounded-angular periphery. The suture follows the abapically first spiral ridge from the peripheral one. The base is subglobular with convex wall, and it is seemingly anomphalous or possibly narrowly phaneromphalous. No peristome part can be observed in the available specimens; the growth lines indicate a prosocline outer lip with a rather deep sinus at the height of the inferred exhalant slit.

Collabral riblets and spiral threads intersect each other with granules on the ramp and the riblets weaken towards the selenizone. The shape of the spiral threads gradually changes into quirinii type ridges on the outer face in abaxial direction; only the latter ones are observed on the base. Instead of riblets, collabral threads are present on the outer face. Seemingly, they are continued also on the base but there the threads are actually composed of short riblets between pairs of the quirinii type ridges and are aligned as apparently continuous collabral threads; they are most conspicuous at the periphery. The selenizone bears dense lunulae.

Remarks - Both specimens are fragments of gradate shells of similar size; the inner mould one shows the conoidal-gradate outline. Though their size suggests early ontogenetic stage, the sharp angulation of the whorls and the dense lunulae seem to indicate nearly full-grown shells. The available information about the shell is satisfactory for the distinction of this species. 
The shell fragments are most similar to Foveolaria hierlatzensis (Szabó, 2009) but its larger shells are without angulation in the growth stage where the size is similar to that of Foveolaria kocsisi n. sp.; the position and morphology of the selenizone, and the ramp are also different. The selenizone lies clearly above the angulation in F. kocsisi n. sp. in the level of the ramp, however, it blunts the angulation in $F$. hierlatzensis, forms a third surface between the ramp and the outer face, and angled to both. The ramp is flattish concave in $F$. kocsisi n. sp. but convex in $F$. bierlatzensis.

Foveolaria jancsii (Szabó, 2009) has convex ramp, and coeloconoidal shell with less markedly gradate outline, differently from F. kocsisi n. sp.

Distribution - Beds with mixed fauna of Obtusum to Ibex Zones (Upper Sinemurian to lowermost Pliensbachian), Kericser, Lókút, Bakony Mts, Hungary.

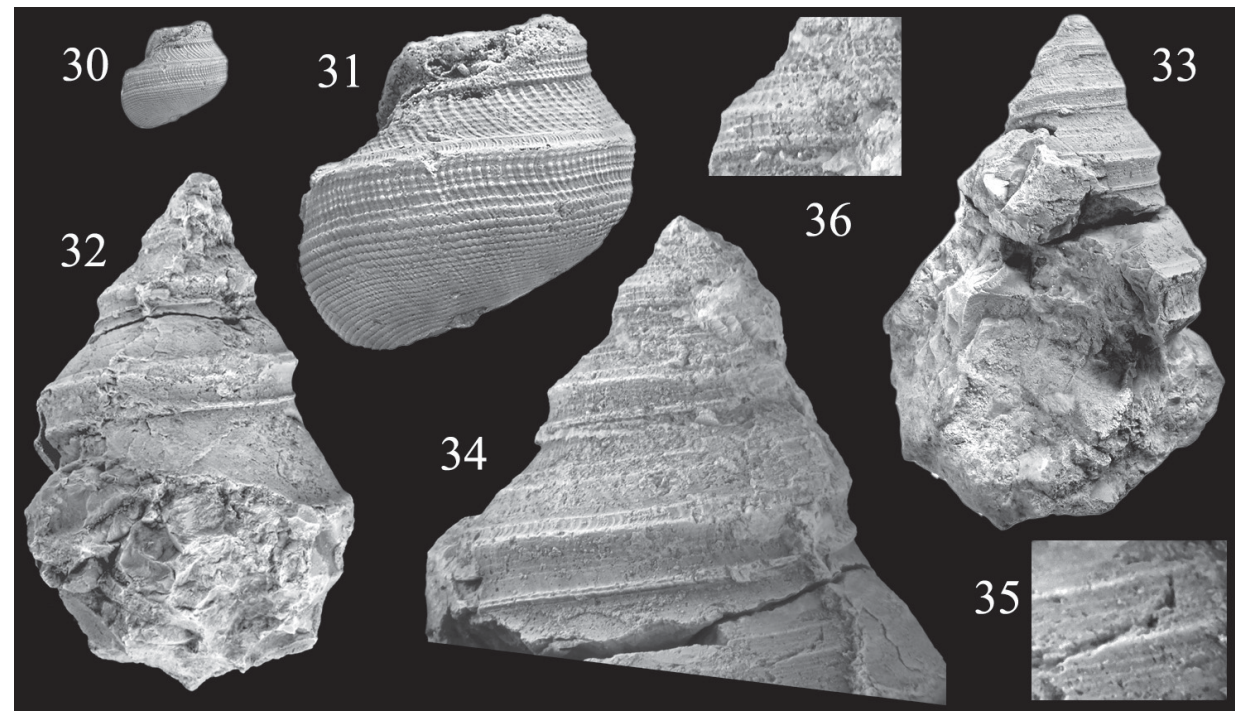

Figs 30-36. New species of Foveolaria n. gen. from the Bakony Mts, Hungary localities of the Hierlatz Limestone Formation. - 30-31. Holotype of Foveolaria kocsisi n. sp., GGIH J.08.9.1. from beds with Obtusum to Ibex Zones (Upper Sinemurian to Lower Pliensbachian, Lower Jurassic) mixed fauna in Hierlatz Limestone at Kericser-dűlő, Lókút, Bakony Mts, Hungary. - 30. The only preserved whorl and base parts, $\times 1$. -31 . The same in $\times 3.5$ magnification for the details. $-32-36$. Holotype of Foveolaria suemegensis n. sp., GGIH J.08.8.1. from the (?)Upper Sinemurian (Lower Jurassic) Hierlatz Limestone of Mogyorósdomb, Sümeg, Bakony Mts, Hungary. - 32-33. Most informative surface parts of the monotype, $\times 1$. -32 . Nearly parallel view to the inferable peristome plane, showing a short part of the outer lip below the suture. -33 . The shell from the opposite side. -34 . Weakening ornament of the early spire whorls, $\times 2.5$. -35 . Magnified sample view of the obscure ornament on the ramp of the latest whorls, $\times 5$. -36 . Network ornament of the early spire, $\times 4.5$ 
Foveolaria suemegensis n. sp.

(Figs 32-36)

1980 Sisenna cf. procera (Deslongchamps, 1849) - SzABó, p. 55, Pl. I, Figs 2-3.

2009 Wortheniopsis (Sisenna) aff. lokutensis Szabó, 2009 - SzABó, p. 34, Fig. 27A-B.

Type specimen - GGIH J.08.8.1.

Type locality - Mogyorósdomb, Sümeg, Bakony Mts (Hungary).

Type strata - Upper? Sinemurian (Lower Jurassic) Hierlatz Limestone.

Derivation of name - From the name of town Sümeg.

Diagnosis - Shell having rather high spire and slightly acute early teleoconch. Marked angulation of whorl surface providing slightly pagodiform outline. Ramp feebly convex initially then feebly concave on last whorl. Outer face concave, its basal rim similarly angular to whorl surface. Initially abaxial rim of base then angulation at abapical rim of selenizone corresponding to periphery. Base with moderately convex wall. Weak spiral lines ornament whorls, crossed by thin, collabral threads on early whorls with granules at intersections. Two stronger threads in middle of ramp present on all visible whorls, except last one.

Material - Single, fragmentary specimen without earliest whorls and peristome.

Dimensions - Preserved width: $33 \mathrm{~mm}$; earliest measurable spiral angle: $55^{\circ}$; spiral angle on last whorl: $63^{\circ}$.

Description - A clearly gradate shell which has a relatively high spire with slightly acute early teleoconch. No information is available from the protoconch. A marked angulation is present on the whorl surface already from the early shell that causes a slightly pagodiform outline. The ramp is feebly convex on the early whorls but becomes feebly concave for the last whorl. The outer face is concave, its basal rim similarly angular to that on the whorl surface. Initially, the abaxial rim of the base then the angulation at the abapical rim of selenizone corresponds to the periphery. The base seems fairly convex from the available fragment as whole and has a moderately convex wall.

Weak spiral lines ornament the whorls, crossed by thin collabral threads on the early whorls with granules at the intersections. Two marked threads in the middle of the ramp are present on all visible whorls, except the last one. The outer face is ornamented by several equally spaced, obscure spiral striae.

Remarks - The slightly acute spire and the marked, keel-like angulation of the whorls suggested affinity of the species to Pleurotomaria faveolata var. procera J. A. Eudes-Deslongchamps, 1849 drawings (SzaBó 1980) but photos in Fischer \& WeBER (1997) display a specimen as "morphe" procera that is strongly different from the earliest figures and not similar to the Sümeg specimen. The shell is somewhat similar to that of Foveolaria lokutensis (Szabó, 2009) 
therefore the name Wortheniopsis (Sisenna) aff. lokutensis has been given to this species subsequently. Since the earliest parts are slightly acute and the angulations of the whorls are more distinct, keel like, while the shell outline is simply conoidal in F. lokutensis, the ramp is narrower and the outer face is wider than in F. lokutensis, establishing a new species seems satisfactorily supported by the morphology.

Distribution - Upper(?) Sinemurian Hierlatz Limestone, Mogyorósdomb, Sümeg, Bakony Mts, Hungary.

\section{Foveolaria sp.}

(Figs 27-29)

Material - Single early or small sized teleoconch without apical and peristomal parts; GBA 2017/001/0006.

Dimensions - Preserved height: $5.5 \mathrm{~mm}$, preserved width: $5 \mathrm{~mm}$, spiral angle: $65^{\circ}$.

Description - The available shell is a moderately high turbiniform one with conoidal outline and rather deeply impressed suture. The whorls are convex, initially almost evenly arched but the latest whorl has an obscure angulation that is blunted by the relatively wide, concave selenizone. The outer face is just slightly wider than the selenizone; it is abapically limited by a marked thread that gives also the abaxial rim of the base and the periphery of the shell. The base is subglobose as a whole and has a slightly convex wall; no trace of an umbilicus and no parts of the peristome has been found.

Predominant ornament consists of spiral threads both on the whorls and the base. On the ramp, two thin spiral threads appear on the earliest shell parts subsuturally and gradually strengthen; two thin threads are added along the adapical limiting thread of the selenizone on the latest available whorl. Two spiral threads are on the outer face. Between the peripheral (third) thread and the axis, dense, evenly spaced, simple spiral threads mean the ornament. The suture follows the first spiral thread adaxially from the peripheral one that is why the suture seems so impressed. The only belt with thin collabral threads is found between the suture and the adapical thread, limiting the selenizone on the latest whorl; granules are at the intersections of the threads. The growth lines are very fine, their form is slightly prosocline and prosocyrt between the suture and the selenizone, lunuliform within the selenizone, not observable on the outer face, and slightly prosocline and opisthocyrt on the base.

Remarks - The pair of spiral threads on the ramp resembles Foveolaria suemegensis n. sp.; however, in the similar sized shell part of that species, the ornament is different; it forms a network of evenly strong spiral and collabral threads. 
Moreover, the selenizone is lying in the plain of the ramp while angled to the ramp in Foveolaria sp. In this latter character, Foveolaria sp. is similar to Foveolaria globosa n. sp., which has more rounded whorls and base and a not concave outer face. Foveolaria conoidea n. sp. also has a selenizone, blunting the angulation of the whorl surface but the steep, flat-concave ramp and the less impressed suture distinguish it from Foveolaria sp.

Distribution - Within the Sinemurian to lowermost Pliensbachian interval (Lower Jurassic) of the Hierlatz Limestone Formation in Hierlatz Alpe, Hallstatt, Austria.

$$
\begin{gathered}
\text { Superfamily Eotomarioidea Ulrich et Scofield, } 1897 \\
\text { Family Gosseletinidae Wenz, } 1938 \\
\text { Subfamily Gosseletininae Wenz, } 1938 \\
\text { Genus Cyclostomaria Szabó, } 1980
\end{gathered}
$$

Type species - Cyclostomaria monarii Szabó, 2008, misidentified as Pleurotomaria suessii Hörnes, 1853 in the original genus designation.

$$
\text { Cyclostomaria praemonarii n. sp. }
$$

(Figs 37-40)

Type specimen - GBA 2017/001/0001.

Type locality - Hierlatz Alpe, Hallstatt (Austria).

Type strata - Hierlatz Limestone from the Sinemurian to lowermost Pliensbachian (Lower Jurassic) interval.

Derivation of name - Referring to the stratigraphically younger [Davoei to Margaritatus Zone (Pliensbachian), Lower Jurassic] C. monarii.

Diagnosis - Low spired shell, consisting of whorls with rounded cross-section, two angles at spire and umbilical suture lines, respectively. Top of convexity on whorls in higher position than suture, convex ramp connecting them. Suture running at periphery of former whorl. Base low with convex wall and broad umbilicus. Selenizone between two cords, concave, rather wide and placed at outer face little below top line of whorl. Subregularly repeating, collabral riblets on ramp, crossed by single cord along top of whorl; nodules at intersections. Dense spiral threads between selenizone and periphery; base seemingly smooth. Selenizone without lunulae and spiral ornament.

Material - A worn, shelly whorl-fragment, surrounding also cross-section of two previous whorls.

Dimensions - Height of preserved whorl: $9.5 \mathrm{~mm}$, width: $21.5 \mathrm{~mm}$.

Description - The remnants indicate a low, almost planispiral shell that has axially round whorl cross-sections; scar of the broken former whorls shows pres- 
ence of a rather wide umbilicus. A concave selenizone runs well above the midwhorl but somewhat below the most adapical line of the whorl; the belt between the selenizone and the impressed (upper) suture is rather wide and mostly convex but a narrow concave band accompanies the suture. The suture follows the periphery of the former whorl.

The ornament is poorly preserved but the coarser elements are observable. Subregularly repeated, unequally strong riblets are visible in the belt between the selenizone and the adapical suture. Their shape is almost straight in slightly prosocline orientation with a short prosocyrt part along the selenizone. Weaker riblets or thick growth lines seem to be developed also on the outer whorl face occasionally. Two cords, the strongest spiral ornamental elements, limit the selenizone. At the first third of the distance toward the adapical suture from the selenizone, single marked spiral thread is visible and two weak threads are also present between the aforesaid one and the cord along the selenizone. Between the strongest spiral thread on the ramp and the selenizone, the collabral riblets weaken; nodules are at crossings with the riblets. The outer face is covered by dense spiral threads of unequal strength, crossed only by strongly prosocyrt growth-lines, which are visible only in few spots. No lunulae are observable in the selenizone; the probably delicate growth-lines are not observable on the available specimen. Preserved parts of the outermost base zone are smooth.

Remarks - The available shelly fragment well agrees with the penultimate whorl of the type specimens of Cyclostomaria monarii in its dimensions and shape. However, the almost full absence of the spiral ornament on the adapical

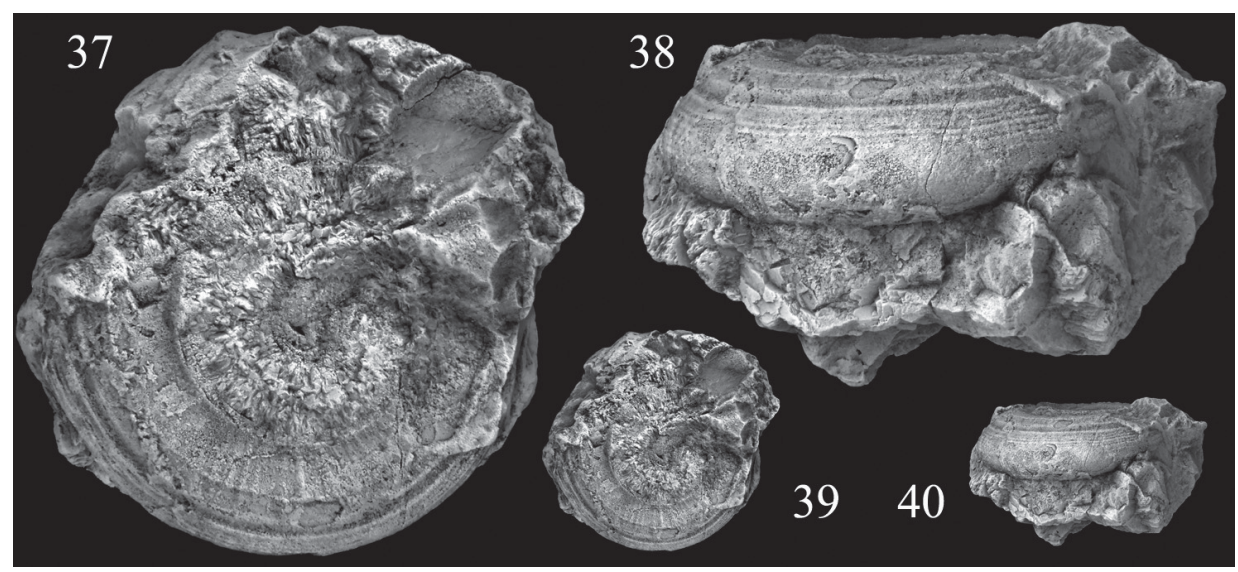

Figs 37-40. Holotype of Cyclostomaria praemonarii n. sp. from the Sinemurian to lowermost Pliensbachian interval (Lower Jurassic) of the Hierlatz Limestone in the Hierlatz Alpe, Hallstatt, Austria, GBA 2017/001/0001. - 37-38. Magnified apical and lateral views, $\times 2$. - 39-40. The same views without magnification 
part of the whorl means a significant difference that distinguish this specimen from C.monarii, which has a dense, subregular network ornament adapically and abapically from the selenizone at corresponding shell size.

Distribution - Within the Sinemurian to lowermost Pliensbachian interval (Lower Jurassic) of the Hierlatz Limestone Formation in Hierlatz Alpe, Hallstatt, Austria.

\section{CONCLUSION}

Occurrence of Wortheniopsis in the Lower Jurassic Hierlatz Limestone Formation extends the time span of this genus to the Sinemurian. Since the plan of the shells is near to each other and some rare morphological details, e. g. the characteristic quirini type ridges, also support it, the species group of Foveolaria n. gen. is regarded as related to Wortheniopsis, therefore belonging also to the same family, tentatively Pithodeidae. Foveolaria has been known from Lower Jurassic (Sinemurian to Pliensbachian) strata with an explosion like speciation in the Sinemurian then with gradually decreasing species number. The latest specimen is known from the Margaritatus Zone (Upper Pliensbachian, Lower Jurassic).

Cyclostomaria has not yet been reported from the Hierlatz Alpe outcrops. Since the faunas in this locality are mostly Sinemurian, and the occurrences of the type species are all Pliensbachian, Cyclostomaria praemonarii n. sp. is a possible ancestor of $C$. monarii. The latest verified species of this genus [C. semiornata (Stoliczka in Laube, 1867)] (SzABó 1980, p. 64; GRÜNDEL 2012, p. 208) is from the Late Bathonian to Early Callovian of Balin (Poland) but the post-Triassic survival of Gosseletinidae may last to the Cretaceous (SzABó 1980, p. 64).

Acknowledgements - I am thankful to A. Kaim (Warsaw, Poland) and S. Monari (Padua, Italy) for critical reading and improving the manuscript, and to B. Erdei (Budapest) for the linguistic emendation. Thanks to the courtesy of S. Monari for the authentic information on gastropods of Marmolada Limestone.

\section{REFERENCES}

Bouchet P., Rocroi J.-P., Frýda J., Hausdorf B., Ponder W., Valdés A. \& Warén A. 2005: Classification and nomenclator of gastropod families. - Malacologia 47(1-2): 1-397.

Вӧнм J. 1895: Die Gastropoden des Marmolatakalkes. - Palaeontographica 42: 211-308.

Eudes-Deslongchamps J. A. 1849: Mémoires sur les Pleurotomaries des terrains secondaires du Calvados. - Mémoires de la Société Linnéenne de Normandie 8: 1-157, Pls 1-18.

Fischer J.-C. \& Weber C. 1997: Volume II, Gastéropodes Jurassiques. - In: Fischer J. C. (ed.): Révision critique de la Paléontologie Française, incluant la réedition de la original. - pp. $300+$ 622, Pls 451; Paris, Masson \& Muséum national d'Histoire naturelle. 
Frýda J., Nützel A. \& Wagner P. J. 2008: Paleozoic Gastropoda. - In: Ponder W. F. \& LindBERG D. L. (eds): Phylogeny and evolution of the Mollusca. - University of California Press (Berkeley, Los Angeles, London): 239-270.

Geyer G. 1886: Ueber die liasischen Cephalopoden des Hierlatz bei Hallstatt. - Abhandlungen der kaiserlich-königlichen Geologische Reichsanstalt 12: 213-287, 4 Pls.

GRÜNDEL J. 2012: Neubearbeitung der von Laube 1867 beschriebenen Gastropodenfauna aus dem mittleren Jura von Balin/Polen. - Annalen Naturhistorisches Museum Wien A1 14: 193-288.

GRÜNDEL J. \& NÜtzel A. 2015: Gastropoden aus dem oberen Pliensbachium (AmaltheentonFormation) NE Bayerns (Umgebung von Stauf/Dörlbach/Altdorf) (Franken, Süddeutschland). - Zitteliana A55: 45-76.

HAuer F. von 1853: Über die Gliederung der Trias-, Lias- und Juragebilde in den nordöstlichen Alpen. - Jabrbuch der kaiserlich-königlichen Geologischen Reichsanstalt, 4: 715-784.

HAUER F. von 1854a: Beiträge zur Kenntniss der Heterophyllen der österreichischen Alpen. Sitzungsberichte der kaiserlichen Akademie der Wissenschaften, Mathematisch-naturwissenschaftliche Classe 12(5): 861-910.

Hauer F. von 1854b: Beiträge zur Kenntnis der Capricornier der österreichischen Alpen. - Sitzungsberichte der kaiserlichen Akademie der Wissenschaften, Mathematisch-naturwissenschaftliche Classe 13: 94-125.

HAUer F. von 1856: Ueber die Cephalopoden aus dem Lias der Nordöstlichen Alpen. - Denkschriften der kaiserlichen Akademie der Wissenschaften, Mathematisch-naturwissenschaftiche Classe 11: 1-56, Pls 1-25.

International Commission on Zoological Nomenclature 1999: International Code of Zoological Nomenclature. - Fourth Edition, XXIX + 306 pp., London (International Trust for Zoological Nomenclature). http://www.iczn.org/iczn/index.jsp

KitTl E. 1894: Die Triadischen Gastropoden der Marmolata und verwandter Fundstellen in der weissen Riffkalken Südtirols. - Jahrbuch der kaiserlich-königlichen Geologischen Reichsanstalt 44(1): 99-182, Pls 1-6.

Kittl E. 1899: Die Gastropoden der Esinokalke, nebst einer Revision der Gastropoden der Marmolatakalke. - Annalen des kaiserlich-königlichen naturhistorishen Hofmuseums 14: 1-237, Pls 1-18.

Knight J. B., Cox L. R., Keen A. M., Smith A. G., Batten R. L., Yochelson E. L., Ludbrook N. H., Robertson R., Yonge C. M. \& Moore R. C. 1960: Mollusca - General features, Scaphopoda, Amphineura, Monoplacophora, Gastropoda - General features, Archaeogastropoda and some (mainly Paleozoic) Caenogastrpoda and Opisthobranchia. In: Moore R. C. \& Pitrat C. W. (eds): Treatise on Invertebrate Paleontology, Part I, Mollusca 1. - The University of Kansas Press, Lawrence, XXIII + 351 pp.

Kunn O. 1936: Die Fauna des Amaltheentons (Lias $\delta$ ) in Franken. - Neues Jabrbuch für Mineralogie, Geologie und Paläontologie, [B], Beilagen-Band 75: 231-311.

MARIAni E. 1896: Appunti di paleontologia Lombarda. - Atti della Società italiana di scienze naturali e del Museo civico di storia naturale di Milano 36: 113-137, 3 Pls.

Orbigny A. D' 1851-1860. Paléontologie Française. Description zoologique et géologique de tous les animaux mollusques et rayonnés fossiles de France, comprenant leur application a la reconnaissance des couches. Terrains jurassiques. Tome 2, contenant les gastéropodes. - Masson, Paris, 621 pp.

Pchelincev V. F. \& Korob kov I. A. 1960: Osnovy Paleontologii, Molliuski, Bhukhonogie. (Fundamentals of palaeontology. Molluscs, Gastropods). - Nauka, Moskva, 360 pp., 28 Pls.

RAKús M. 1999: Liassic ammonites from Hierlatz, Austria. - Abhandlungen der Geologishen Bundesanstalt 56(2): 343-377.

Sieberer K. 1907: Die Pleurotomarien des Schwäbischen Jura. - Palaeontographica 54: 1-68. 
STOLICZKa F. 1861: Über die Gastropoden und Acephalen der Hierlatz-Schichten. - Sitzungsberichte der matematisch-naturwissenschaftliche Classe der kaiserlich-königlichen Akademie der Wissenschaften 43: 157-204, Pls 1-7.

Szabó J. 1980: Lower and Middle Jurassic Gastropods from the Bakony Mountains (Hungary). Part II. Pleurotomariacea and Fissurellacea (Archaeogastropoda). - Annales historico-naturales Musei nationalis hungarici 72: 49-71.

SzABó J. 2009: Gastropods of the Early Jurassic Hierlatz Limestone Formation; part 1: a revision of type collections from Austrian and Hungarian localities. - Fragmenta Palaeontologica Hungarica 26: 1-108.

VöRös A. 1991: Hierlatzkalk - a peculiar Austro-Hungarian Jurassic facies. - In: LOBITZER H. \& CsÁszÁr G. (Eds): Jubiläumsschrift 20 Jahre Geologische Zusammenarbeit Österreich-Ungarn. - Wien, pp. 145-154.

WAgner P. J. 2002: Phylogenic relationships of the earliest anisotrophically coiled Gastropoda. Smithsonian Contributions to Paleobiology 88: 1-152. https://doi.org/10.5479/si.00810266.88.1

Wenz W. 1938-1944. Gastropoda. Teil I: Allgemeiner Teil und Prosobranchia. - In: SCHIndewolf O. H. (Ed.): Handbuch der Paläozoologie, Bd. 6: 1639 pp.; Berlin, Verlag Bornträger; 1938: 1-480; 1939: 481-720; 1940: 721-960; 1941: 961-1200; 1943: 1201-1506; 1944: 1507-1639. 